\title{
Effects of Topology and Material on Mechanical Properties of Structures Produced by the Additive Manufacturing Method
}

\author{
Topoloji ve Malzemenin Eklemeli İmalat Yöntemiyle \\ Üretilen Yapıların Mekanik Özelliklerine Etkileri
}

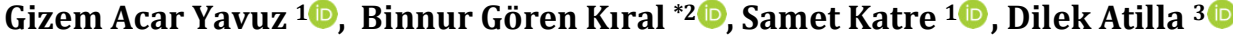 \\ ${ }^{1}$ Dokuz Eylül Üniversitesi Fen Bilimleri Enstitüsü Makine Mühendisliği Anabilim Dalı Mekanik Programı, İzmir, \\ TÜRKIYE \\ 2 Dokuz Eylül Üniversitesi Mühendislik Fakültesi Makine Mühendisliği Bölümü, İzmir, TÜRKIYE \\ 3 İzmir Katip Çelebi Üniversitesi Mühendislik ve Mimarlık Fakültesi Makine Mühendisliği Bölümü, İzmir, TÜRKIYE \\ Sorumlu Yazar / Corresponding Author*: binnur.goren@deu.edu.tr \\ AtIf șekli/How to cite: ACAR YAVUZ G., GOREN KIRAL B., KATRE S., ATILLA D. (2021) Effects of Topology and Material on Mechanical \\ Properties of Structures Produced by the Additive Manufacturing Method. DEUFMD 23(69), 755-765.
}

\begin{abstract}
The usage area of 3D printers from architecture to heavy industry has been increasing in recent decades. By this process, it is possible to manufacture structures having different geometric configurations to improve the mechanical, vibration, impact, and acoustic properties of the structures. In this study, three-point test specimens with different topologies were produced by the 3D printing method in order to see the effect of the geometric configuration. The specimens having $100 \%$ infill density were produced using PLA (Polylactic Acid), ABS (Acrylonitrile Butadiene Styrene) and PETG (Polyethylene terephthalate glycol-modified) filament materials with the additive manufacturing method, which is the most widely used method in three-dimensional production. Numerical and experimental results are compared for loading conditions at specific force values.

Keywords: 3D printing, Finite element analysis, Three-point bending test, Additive manufacturing.

$\ddot{0} \mathbf{z}$

Son yıllarda mimariden ağır sektöre kadar 3B yazıcıların kullanım alanı artmaktadır. Bu yöntem ile yapıların mekanik, titreşim, darbe ve akustik özelliklerini iyileştirmek için farklı geometrik konfigürasyonlara sahip yapılar üretmek mümkündür. Bu çalışmada, geometrik konfigürasyonun etkisini görmek için farklı topolojilerde üç nokta deney numuneleri 3B baskı yöntemi ile üretilmiştir. $\% 100$ dolgu yoğunluğuna sahip numuneler PLA (Polilaktik asit), ABS (Akrilonitril bütadien stiren) ve PETG (polietilen tereftalat glikolle değişmiş) filament malzemeleri kullanılarak üç boyutlu üretimde en yaygın kullanılan yöntem olan eklemeli imalat yöntemi ile üretilmiștir. Belirli kuvvet değerlerindeki yükleme koşulları için sayısal ve deneysel sonuçlar karş̧laştırılmıştır.
\end{abstract}

Anahtar Kelimeler: 3B baskı, Sonlu eleman analizi, 3 nokta eğme deneyi, Eklemeli imalat. 


\section{Introduction}

Additive manufacturing technologies have made significant progress over the past decades. In this manufacturing process, an object is built by adding successive layers of raw material. Each of these layers can be viewed as a thinly sliced horizontal section of the final object [1]. Chuck Hull is known for his invention of the first threedimensional printer in 1984, which has a Stereolithography (SLA) systems [2]. The stereolithographic technique is based on the principle of solidifying certain parts of the resin layer, which is liquid at room temperature, by means of a laser beam [3]. Fused deposition modeling (FDM), an extrusion-based technology was developed by Scott Crump in 1989 [4]. FDM uses a moving nozzle to extrude a filament of polymer or metal which is heated to its melting point to create a 3D model. ABS, PLA, and PETG are the most used materials in this technique.

With the widespread use of 3D printers, determining the physical properties of the structures produced by this technique has gained importance in recent years. Studies based on the effects of material type, filling rates, orientation, nozzle temperature, and topology on the behavior of the structure under loading have started to take place in the literature. Rebenaque and Requena examined the different filling density rates and different geometries in accordance with UNE-EN ISO 178 (2011) standard [5]. Kołodziej et al. examined printing parameters such as infill density on the modulus of elasticity, maximum stress and deflection value to find the optimal printing parameters. They carried out the static bending tests of the specimens made of PLA [6]. Hernandez et al. determined the tensile, compressive, and flexural properties of printed ABS P340 polymer specimens having different orientations [7]. Harshitha and Rao examined the displacement, tension and shear force values of bolts made of ABS and PLA material by the finite element analysis [8]. Abbot et al. printed PLA, PETG, ABS and TPU square blocks having different infill ratios to compare the numerical simulation and tensile test results. They concluded that the 50\% infill density simulations behaved when compared to that of the dimensions of the $100 \%$ infill density, representing almost double the displacements. They also emphasized that a multi-body model can be considered to closely illustrate the variation in the infill density of $3 \mathrm{D}$ printed structures [9]. Abeykoon et al. examined the effect of different geometries, filling speed, nozzle temperature, and filling pattern conditions. They compared the results to those obtained by the finite element analyses [10]. Sayre investigated the tensile, compression, and bending behaviors of specimens made of ABS considering different printing orientations by the finite element method [11]. Martínez et al. carried out a comparative study to develop the accurate finite element models of laminated tensile test specimens made of FDM having different orientations [12]. Zhou et al. studied the mechanical behavior of PLA specimens under tensile conditions both experimentally and numerically, and the effects of printing pattern and infill density on ultimate tensile strength [13]. Sarvestani et al. investigated the structural responses, failure mechanics, energy absorption capabilities of 3D printed sandwich structures by the tensile and three-point bending tests [14]. They determined the failure mechanism and energy absorption capabilities of the core topology and geometric parameters of the meta-sandwich structures. Ercan et al. [15] investigated the effect of geometry on bending strength of sandwich panels considering four different geometries namely honeycomb, cubic, skeleton, and truss by the three-point bending test and finite element analysis.

The current study aims to investigate the structural responses of 3D printed three-point bending specimens having seven different topologies both experimentally and numerically. Three-point bending specimens were produced using three different materials such as ABS, PLA and PETG in order to also examine the effect of the material type on the mechanical behavior.

\section{Material and Method}

Material properties, geometrical parameters, and core cell topology affect the structural performance and one of the most used topologies is the honeycomb in various engineering applications [14]. Therefore, it is necessary to examine the effect of process parameters on the mechanical performance of the considered structures. The literature is somewhat limited, especially on the mechanical properties of parts processed by low-cost 3D printers. In this study, seven different topologies are examined for three types of 3D printing materials, such as PLA, ABS, and PETG. The PLA 
is formed from one of the most common plastic filaments, a biodegradable [16] and environmentally friendly plastic Polylactic Acid (or Polylactide abbreviated with PLA) derived from starch. It does not smell bad during printing and its fumes are not dangerous, so it does not require special safety measures or forced ventilation. Another most common filament is made of Acrylonitrile Butadiene Styrene (ABS). It is a petroleum-based plastic that is used for many purposes. Its smoke smells bad and is even considered dangerous to health, so it is recommended to use extra ventilation [17] when printing ABS for a long time. The ABS filament is printed on a heated bed, usually covered with Kapton tape, to adhere well, adding cost and complexity to the printer itself. The advantage of ABS over PLA is that the resulting objects are more robust and less brittle, and can resist higher temperatures. Another type of material we used in this study is Polyethylene terephthalate glycol-modified (PETG). The characteristic properties of PETG material are as follows: odorless, little shrinkage rate, hydrophobicity (will not absorb water and as such clog the extruders), outstanding toughness and high impact strength, good liquidity (flows smoothly), high mechanical strength and excellent flexibility, high transparency, good gloss, recyclable. The mechanical properties of these materials are shown in Table 1.

Table 1. Mechanical properties of the ABS, PLA and PETG materials [18].

\begin{tabular}{lccc}
\hline Material & $\begin{array}{c}\text { Modulus of } \\
\text { Elasticity } \\
\text { (MPa) }\end{array}$ & $\begin{array}{c}\text { Poisson's } \\
\text { Ratio }(-)\end{array}$ & $\begin{array}{c}\text { Density } \\
\left(\mathrm{g} / \mathrm{cm}^{3}\right)\end{array}$ \\
\hline ABS & 2100 & 0.35 & 1.03 \\
PLA & 2300 & 0.36 & 1.23 \\
PETG & 2100 & 0.4 & 1.27 \\
\hline
\end{tabular}

\subsection{Design of Test Specimens}

The main purpose of this study is to examine the effect of topology and material on the bending behavior of the 3D printed structures. For this reason, the three-point bending specimens were manufactured using ABS, PLA, and PETG and seven different core topologies were designed for each material according to ASTM D790 [19] and ASTM C393 standards [20]. Dimensions of test specimens are $12.7 \times 20 \times 125 \mathrm{~mm}^{3}$ as shown in Figure 1.

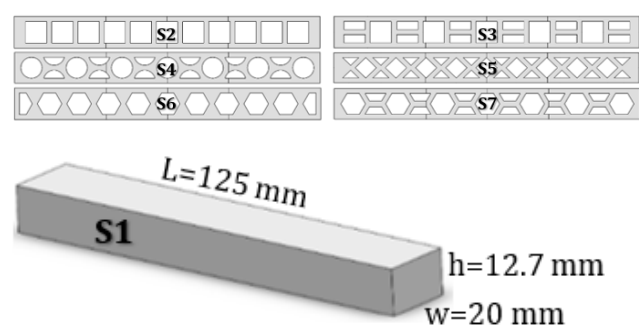

Figure 1. Specimen types

According to the test standard, the support spanto-depth ratio is recommended as 1:16. However, there are thicker specimens in the literature [14]. The minimum vertical distance between geometric shapes is designed as $2 \mathrm{~mm}$. The total filament volumes used and total lateral surface area for each specimen are shown in Table 2.

Table 2. Specimen nomenclature and total surface areas.

\begin{tabular}{ccc}
\hline Specimen & $\begin{array}{c}\text { Total Surface } \\
\text { Area }\left(\mathrm{mm}^{2}\right)\end{array}$ & $\begin{array}{c}\text { Filament Volume Used } \\
\left(\mathrm{mm}^{3}\right)\end{array}$ \\
\hline S1 & 8683.00 & 32481.54 \\
S2 & 14673.82 & 15186.84 \\
S3 & 16490.56 & 17359.78 \\
S4 & 15998.36 & 18986.89 \\
S5 & 18452.18 & 20260.89 \\
S6 & 13759.78 & 19220.99 \\
S7 & 16473.53 & 17624.09 \\
\hline
\end{tabular}

\subsection{Printing of Test Specimens}

Three-point bending test specimens were produced by fused deposition modeling (FDM), which creates complex objects from molten plastic extruded through a nozzle. The plastic filament (thermoplastic material) is wound on a coil and unreeled to supply material to the extrusion nozzle, while the nozzle or the object 
(or both) is moved along three axes by a computer-controlled mechanism, and the material hardens immediately after extrusion. The specimens modeled using by SolidWorks ${ }^{\mathrm{TM}}$ software were converted into STL file format to open the model in the slicer programs. In order to model the specimens to be produced from ABS material, 3D solid models in STL file format were separated layer by layer with the threedimensional slicing program PrusaSlicer [21]. Another slicing program, CURA, was used for PLA and PETG specimens. Among the specimens prepared for this study, PLA specimens were produced with Ultimaker/2+ and ABS and PETG materials were produced by Prusa i3 MK3 3D printers (Table 3 ). Although the slicing programs are different, all advanced settings are arranged in the same way.

Table 3. Specifications regarding preparation

\begin{tabular}{lllc}
\hline & ABS & PLA & PETG \\
\hline \multirow{3}{*}{ Printer } & Prusia i3 & Ultimaker/2+ & Prusia \\
& MK3 & & MK3 \\
& & & CURA \\
Software & PrusaSlicer & CURA 4.5.0 & 4.5 .0 \\
& 2.2 .0 & & \\
\hline
\end{tabular}

In this study, ABS, PLA, and PETG filaments having $1.75 \mathrm{~mm}$ diameter produced by Porima3D [18] were used as printing materials. The recommended nozzle temperature during production for ABS material is specified as 220 $255^{\circ} \mathrm{C}$, and heater plate temperature as 80 $100^{\circ} \mathrm{C}$ in the product catalog. In this study, nozzle temperature $250^{\circ} \mathrm{C}$ and heater plate temperature $90^{\circ} \mathrm{C}$ were selected. For PLA material, the recommended nozzle temperature during production is specified as $200-220^{\circ} \mathrm{C}$ and heater plate temperature as $60-75^{\circ} \mathrm{C}$ in the product catalog. During printing, the nozzle temperature was kept at $215^{\circ} \mathrm{C}$ and the temperature of the heater plate at $60^{\circ} \mathrm{C}$. In the product catalog for PETG, the recommended nozzle temperature and plate temperature during printing are specified as $230-265^{\circ} \mathrm{C}$ and $90-100^{\circ} \mathrm{C}$, respectively. In the printing of PETG specimens, the temperature values of the nozzle and heater plate were set to $245^{\circ} \mathrm{C}$ and $90^{\circ} \mathrm{C}$, respectively. The manufacturing tolerance for the $\mathrm{x}$ and $\mathrm{y}$ axes is $\pm 0.05 \mathrm{~mm}$ for all materials. All specimens have $100 \%$ infill density, layer height of $0.2 \mathrm{~mm}$ and were produced by selecting the rectilinear infill pattern. Details about the printing parameters are shown in Table 4 . Besides, no support material was needed in the production of specimens placed horizontally on the plate of the device.

Table 4. Printing parameters

\begin{tabular}{llll}
\hline & ABS & PLA & PETG \\
\hline $\begin{array}{l}\text { Nozzle } \\
\text { diameter }\end{array}$ & $1.75 \mathrm{~mm}$ & $1.75 \mathrm{~mm}$ & $1.75 \mathrm{~mm}$ \\
$\begin{array}{l}\text { Layer height } \\
\text { Infill pattern }\end{array}$ & $0.2 \mathrm{~mm}$ & $0.2 \mathrm{~mm}$ & $0.2 \mathrm{~mm}$ \\
$\begin{array}{l}\text { Rectilinfill } \\
\text { Nozzle }\end{array}$ & 100 & Rectilinear & Rectilinear \\
temperature & $250^{\circ} \mathrm{C}$ & $215^{\circ} \mathrm{C}$ & $245^{\circ} \mathrm{C}$ \\
$\begin{array}{l}\text { Heater plate } \\
\text { temperature }\end{array}$ & $90^{\circ} \mathrm{C}$ & $60^{\circ} \mathrm{C}$ & $90^{\circ} \mathrm{C}$ \\
$\begin{array}{l}\text { Production } \\
\text { tolerance } \\
\text { for x-y axes }\end{array}$ & $\pm 0.05 \mathrm{~mm}$ & $\pm 0.05 \mathrm{~mm}$ & $\pm 0.05 \mathrm{~mm}$ \\
\hline
\end{tabular}

\subsection{Three-Point Bending Tests}

Three-point bending tests were conducted on the specimens by using Shimadzu AG-X tensile test machine. The experimental setup shown in Figure 2 was used to determine the three-point bending capability of different cellular shapes on 3D printing specimens to evaluate their flexural stiffness. The transverse load was applied at a displacement rate of $1 \mathrm{~mm} / \mathrm{min}$ at room temperature. The load was applied by a central roller on the midpoint of the specimen while two rollers support the specimen from the bottom. The length of the support span was chosen as $\mathrm{L}_{\mathrm{s}}=50 \mathrm{~mm}$. 

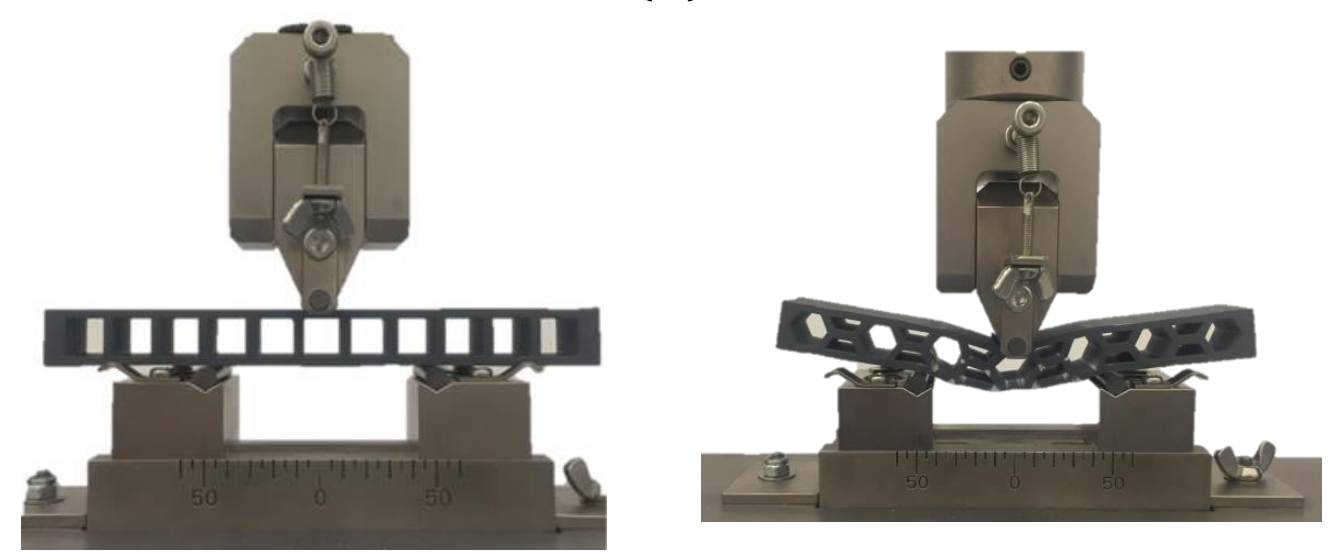

Figure 2. Three-point bending test configurations of 3D printed structures.

\section{Results and Discussions}

\subsection{Three-Point Bending Tests}

In this section, the experimental three-point bending test results of the 3D printed specimens are presented. Three-point bending test specimens were prepared in such a way that force was applied to their weakest cross-section to evaluate the section effect more easily. Figure 3 shows the experimental three-point bending load-displacement curves for specimens produced with seven different topologies and three different materials. As seen in Figures 3 $(a, b, c)$, specimens $S 1, S 2$ and S3 made of ABS, PLA and PETG materials have similar tendency regardless of the material. When the numerical and experimental results are examined, it is seen that the remaining specimens (S4, S5, S6 and S7) made of PLA material show a fragile behavior. Although PLA is a brittle material, all the specimens made of this material have the maximum load values. Images of deformed specimens resulting from the three-point bending test of seven different designs made of ABS, PLA, and PETG materials can also be seen in this figure. Results obtained by the experiments show the topology has a significant effect on the force-displacement curves. Figure 4 presents the effect of the printing material on the bending stiffness. For the sake of clarity, forcedisplacement curves are given only for specimens S6 and S7. As seen from the figure, bending stiffness and the maximum contact forces of ABS and PETG materials are close to each other. Specimens printed using PLA has higher bending stiffness and contact force than those made from the other two materials. On the other hand, ABS shows more ductile behavior while PLA is more brittle. Although PLA has the maximum contact force, it shows a more brittle behavior. In the light of these results, alternative designs and materials can be selected for different sectors, considering the usage areas of ABS, PLA and PETG materials. While ABS, PLA, and PETG materials are used in different sectors, different design criteria can be determined according to the desired strength and strain values. Thus, small changes made in the topology allow materials to create alternatives to each other. Figure 5 presents the maximum loads and corresponding displacements for seven different designs produced with ABS, PLA, and PETG materials obtained by the three-point bending tests. As seen from the figure, specimen S1 having a solid rectangular cross-section (12.7 $\mathrm{mm} \times 20 \mathrm{~mm}$ ) are stiffer than the other specimen types as expected.

There is a slight difference in the design between the S2 and S3 specimens. However, as seen in Figure 5 (b), while the displacement values of S2 specimens made of PLA and PETG materials at maximum load are higher, they are higher in S3 specimen made of ABS. It was aimed to use less material in the S7 specimen than in the S6 specimen, an $8.31 \%$ reduction was achieved in the volume of the filament used as shown in Table 2. As shown in Figure 5(a), the maximum load values of specimen S7 made of ABS and PLA materials are lower than those of S6 while specimen S7 made of PETG reaches a higher load value than that of specimen S6.When the displacement values of specimens S6 and S7 at the maximum loads are compared, it is observed that the displacement values of specimen S7 increase independently of all the materials used in this study. 
DEÜ FMD 23(69), 755-765, 2021

\section{(a) ABS}
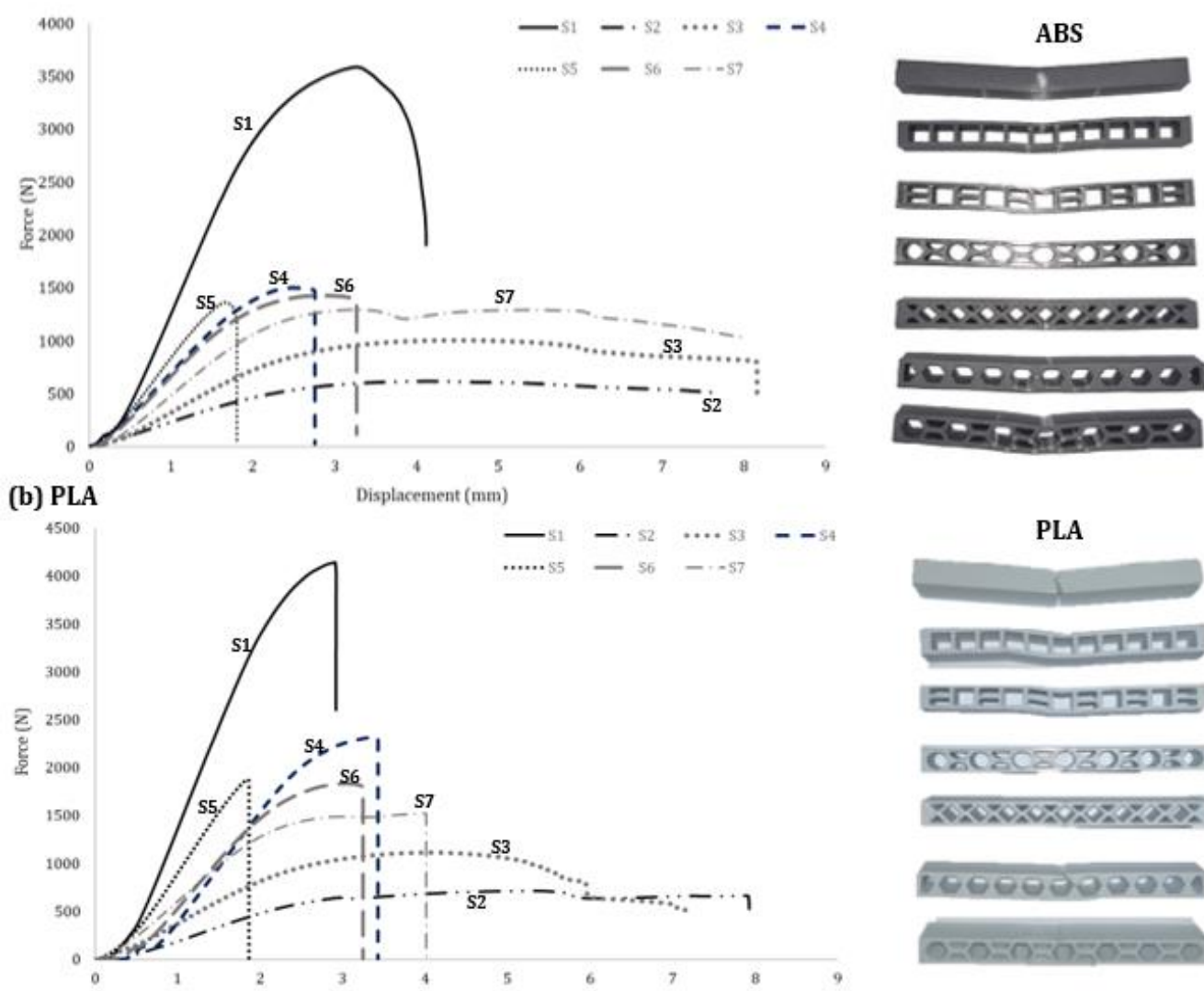

PLA
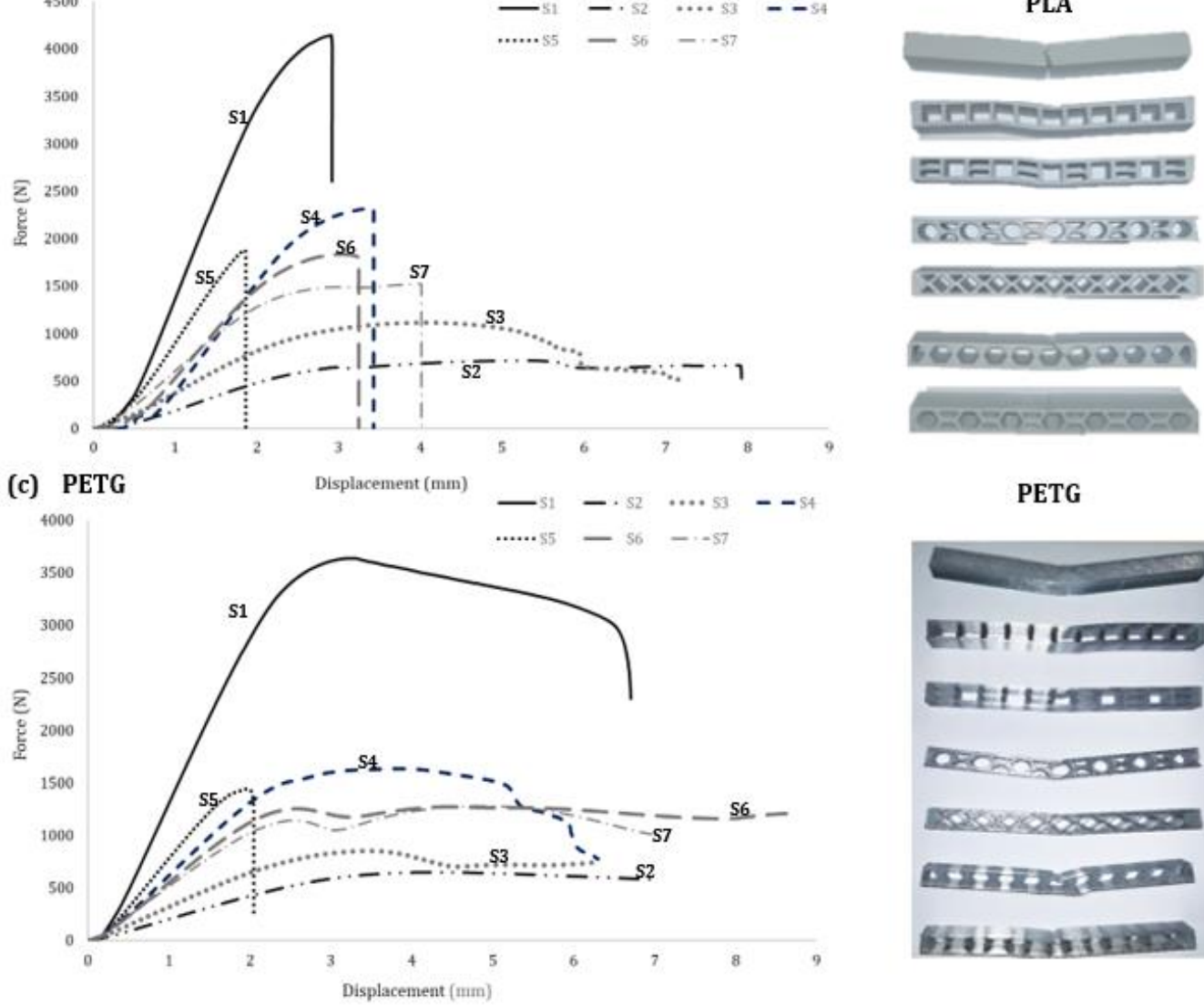

PETG

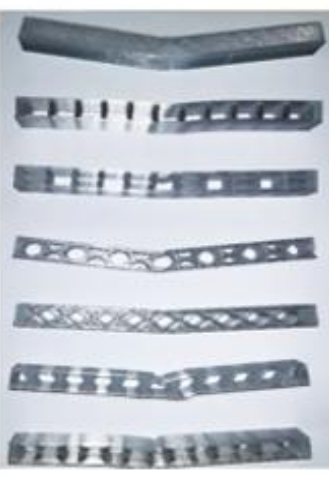

Figure 3. Bending characteristics of 3D printed specimens with different lattice structures. 


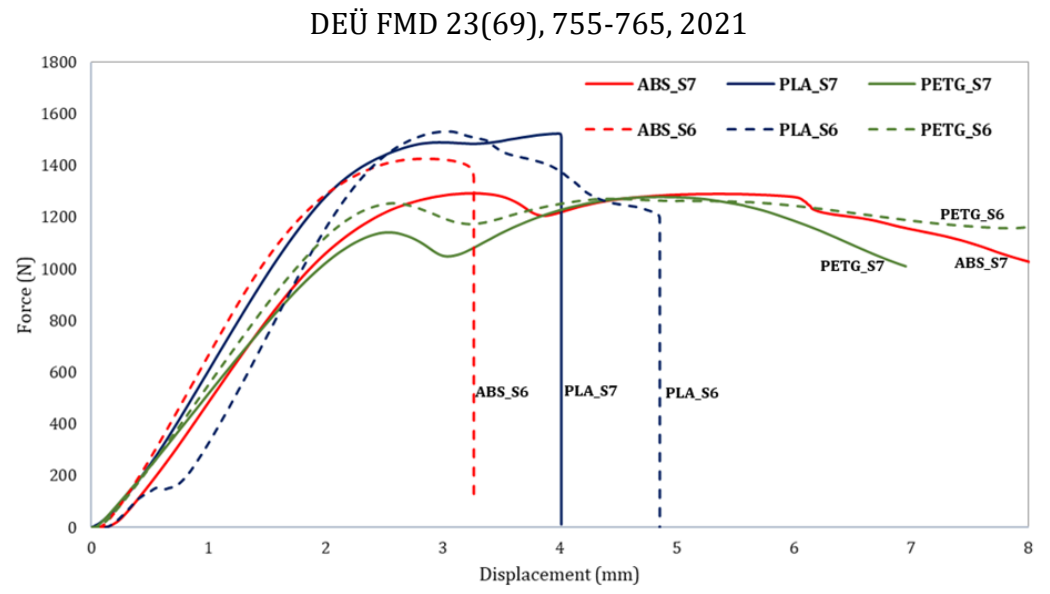

Figure 4. Comparison of the 3D printing material for hexagonal lattice.

(a)

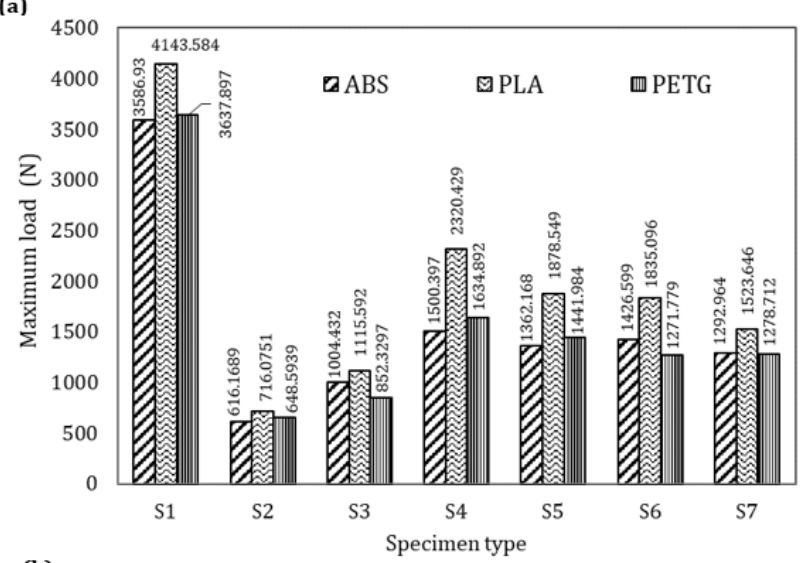

(b)

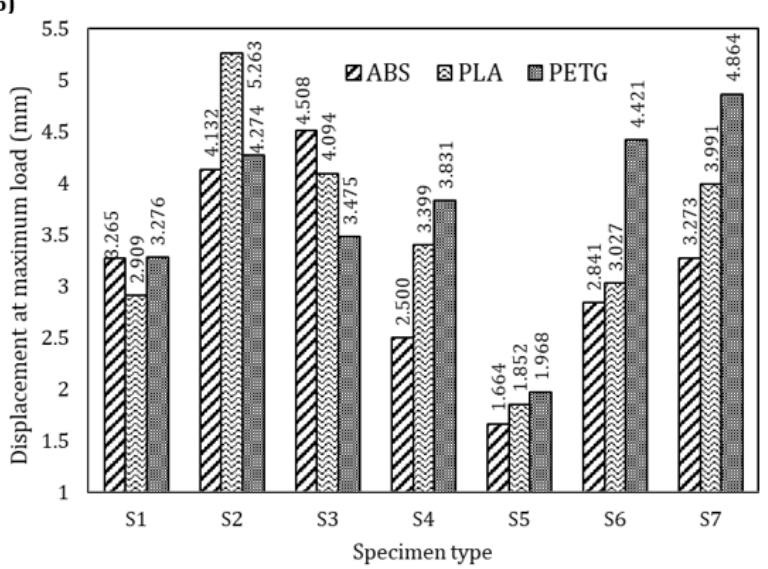

Figure 5. (a) The maximum loads and (b) corresponding maximum displacements obtained by the experiments. 


\subsection{The Finite Element Analyses}

In this study, the displacements of the designs with different cellular structures on the y-axis under bending loading were calculated by the finite element analysis software SolidWorksTM Simulation. Figure 6 shows the exemplary finite element model and the boundary conditions for the three-point bending specimen having the hexagonal lattice structure selected as an example. For the numerical simulation of the three-point bending test, two fixed supporting rods are made of AISI 1015 steel with radii of 3 $\mathrm{mm}$. The load was subjected to the top rod on the three-point bending specimen using contact sets. The contact properties between specimen and rods were frictionless, no penetration and nodeto-surface. The stress-strain relation of PLA, ABS, and PETG was assumed as multi-linear behavior using data obtained by the experiments. The finite element model consists of 300522 nodes and 192617 tetrahedron elements having 10 nodes and a total of 30 degrees of freedom. By both the experimental examinations and finite element analyses, it is observed that the printing materials especially PLA exhibit an anisotropy having multi-directions.

During the experiment, the stiffness of the 3D printed structures changes dynamically in time since there are areas that break even at low loadings below the yield strength. Since it was not possible to determine which region, direction and time the break occurred, the finite element analysis was carried out mainly for the purpose of showing the topological effect. It should be stated that determining the exact force and displacement values from the finite element analysis is complicated, especially for PLA, which exhibits a highly brittle behavior. Therefore, the tendency of the numerical results obtained is compared with the experimental results.

Figure 7 presents the comparison of displacements in the $y$-direction of 3D printed specimens subjected to the load of $300 \mathrm{~N}$ obtained by experimental and finite element analyses. Similar tendency and satisfactory agreement can be observed in the displacement values between the numerical and experimental results for all specimens made of PETG and ABS except S4 and S6 made of PLA. The finite element analyses have been performed for many load values below the yielding point and similar results have been found. In this paper, the displacement results are presented for only 300 $\mathrm{N}$. After the yielding point it has been observed that the numerical and experimental results are not agreed upon, as well as the fracture may occur in some region before the yield point. Figure 8 shows the comparison of the failure behavior observed by experiments and finite element analyses.

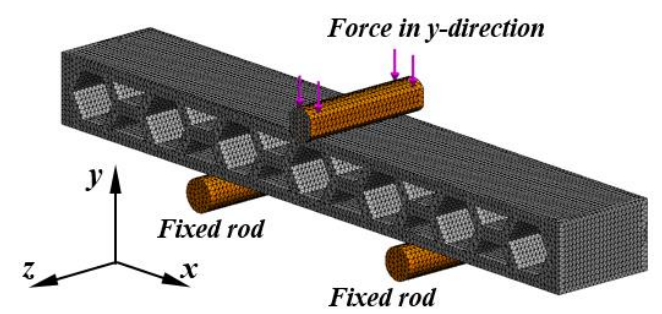

Figure 6. Bending characteristics of 3D printed

A good agreement is observed in the deformation shapes. As seen from all the figures given in the table, it can be concluded that the lower region of the structures should be strengthened, where the maximum principal stresses occur in these regions that cause the failure of the brittle materials. It can be concluded that printing directions besides topology play important role in the failure mechanisms. When the results are evaluated, as a general design criterion, it can be proposed to thicken the bottom plate of the structures produced by additive manufacturing method subjected to such loads. As seen from the deformed shapes of the three-point bending specimens obtained by the experiments, due to the occurrence of fractures in some regions as well as plastic deformation, it is not sufficient to consider only the von Mises criterion for evaluation. For this reason, the maximum principal stress distribution that occurred in the specimen under loading is given for the evaluation of the failure mechanism. 
DEÜ FMD 23(69), 755-765, 2021

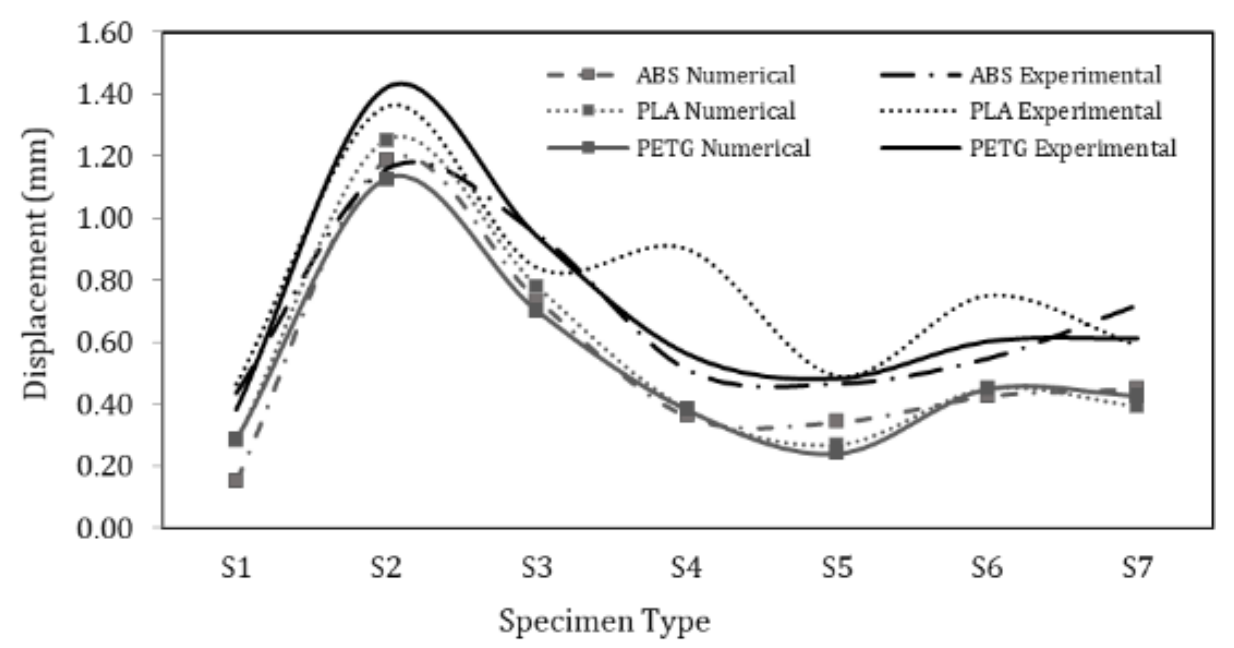

Figure 7. Numerical and experimental displacement values at mid-point of the specimens.

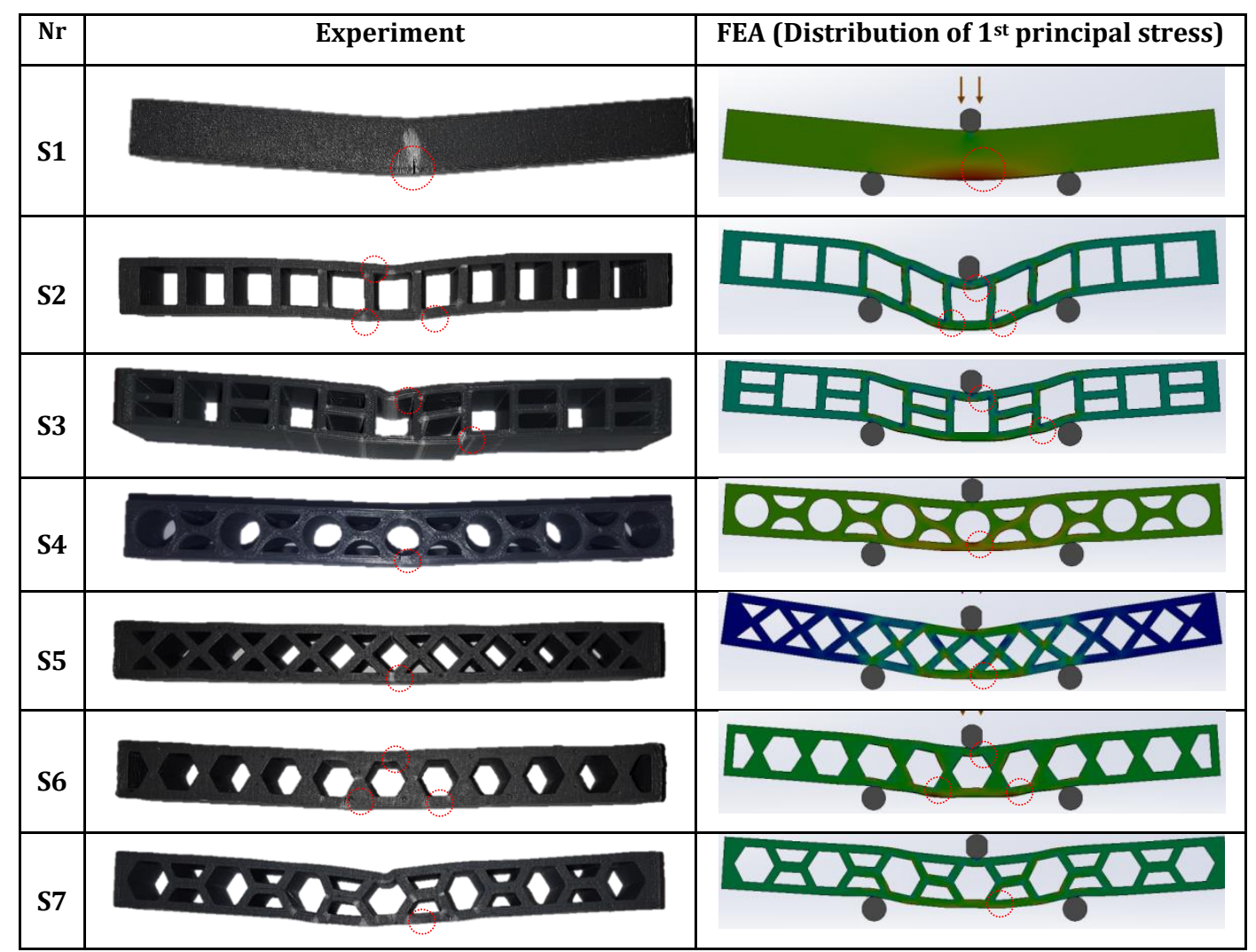

Figure 8. Deformations of three-point bending specimens by experiments and numerical analyses. 


\section{Conclusions}

In this study, three-point bending specimens having seven different lattice topologies were produced using three different printing materials namely PLA, ABS, and PETG. The maximum load that all the specimens can carry and the corresponding displacement values were determined by the experiments. Finite element analyses were carried out by using the multilinear displacement-force relation and bending stiffness obtained from experimental studies. Results obtained by experiments and numerical investigations show that the specimen which can bear the highest load value is S1 with rectangular cross section as expected. It is seen that specimens made of ABS show more ductile behavior while those made of PLA remain fragile.

Although PLA could withstand higher load values, it is clear that they show more brittle behavior when the maximum displacement values are considered. The results may provide a reference for alternative design and material selection for different sectors, considering the usage areas of ABS, PLA and PETG materials. The printing materials especially PLA exhibit an anisotropic behavior with multi-directions. The stiffness of the 3D printed structures under loading changes dynamically. To determine the accurate mechanical behavior of the 3D printed structures under loading by the finite element analyses, material characteristics for printing direction should be known. After yielding point the numerical and experimental results do not agree, as well as fracture may occur in some region before the yield point.

\section{References}

[1] Tarang, Y.E. 2015.3D printing additive manufacturing. International Education and Research Journal, 1(4), 21-23.

[2] Horvath, J. 2014. A Brief History of 3D Printing. In Mastering 3D Printing (pp. 3-10). A Press, Berkeley, CA.

[3] Özsoy, K., Duman, B. 2017. Usability of additive manufacturing (3D printing) technologies in education (in Turkish). International Journal of 3D Printing Technologies and Digital Industry, 1(1), 3648.

[4] Kai, C. C., \& Fai, L. K. 1997. Rapid Prototyping. Nanyang Technological University.

[5] Rebenaque, A. G., \& González-Requena, I. 2019. Study of bending test of specimens obtained through FDM processes of additive manufacturing. Procedia Manufacturing, 41, 859-866.

[6] Kołodziej, A., Żur, P., \& Borek, W.2019. Influence of 3D-printing parameters on mechanical properties of PLA defined in the static bending test. European Journal of Engineering Science and Technology, 2(1), 65-70.

[7] Hernandez, R., Slaughter, D., Whaley, D., Tate, J., \& Asiabanpour, B. 2016. Analyzing the tensile, compressive, and flexural properties of 3D printed ABS P430 plastic based on printing orientation using fused deposition modeling. In 27th Annual International Solid Freeform Fabrication Symposium, Austin, TX (pp. 939-950).

[8] Harshitha, V., \& Rao, S. S. 2019. Design and analysis of ISO standard bolt and nut in FDM 3D printer using PLA and ABS materials. Materials Today: Proceedings, 19, 583-588.

[9] Abbot, D. W., Kallon, D. V. V., Anghel, C., \& Dube, P. 2019. Finite element analysis of $3 \mathrm{D}$ printed model via compression tests. Procedia Manufacturing, 35, 164173.

[10] Abeykoon, C., Sri-Amphorn, P., \& Fernando, A. 2020. Optimization of fused deposition modeling parameters for improved PLA and ABS 3D printed structures. International Journal of Lightweight Materials and Manufacture, 3(3), 284-297.

[11] Sayre, R. 2014. A comparative finite element stress analysis of isotropic and fusion deposited 3D printed polymer. Rensselaer Polytechnic Institute Hartford, Connecticut, USA.

[12] Martínez, J., Diéguez, J. L., Ares, E., Pereira, A., Hernández, P., \& Pérez, J. A. 2013. Comparative between FEM models for FDM parts and their approach to a real mechanical behavior. Procedia Engineering, 63, 878-884.

[13] Zhou, X., Hsieh, S. J., \& Ting, C. C. 2018. Modelling and estimation of tensile behavior of polylactic acid parts manufactured by fused deposition modelling using finite element analysis and knowledge-based library. Virtual and Physical Prototyping, 13(3), 177-190.

[14] Sarvestani, H. Y., Akbarzadeh, A. H., Mirbolghasemi, A., Hermenean, K. 2018. 3D printed meta-sandwich structures: Failure mechanism, energy absorption and multi-hit capability. Materials \& Design, 160, 179-193.

[15] Ercan, N., Kanber, B., Yunus, D. E. 2018. Investigation of bending behavior of sandwich panels with different cellular structures by using finite element method (in Turkish). 2nd International Symposium on Innovative Approaches in Scientific Studies, 11 (3), 232-235.

[16] Ray, S. S., \& Okamoto, M. 2003. Biodegradable polylactide and its nanocomposites: opening a new dimension for plastics and composites. Macromolecular Rapid Communications, 24(14), 815-840.

[17] Byrley, P., George, B. J., Boyes, W. K., Rogers, K. 2019. Particle emissions from fused deposition modeling 3D printers: Evaluation and meta-analysis. Science of The Total Environment, 655, 395-407.

[18] Porima. Printing Filament. Available: https://www.porima3d.com, 2020.

[19] Standard A. ASTM D790. Standard test methods for flexural properties of unreinforced and reinforced 
DEÜ FMD 23(69), 755-765, 2021

plastics and electrical insulating materials, West Conshohocken, PA, 2017.

[20] Standard A. ASTM C393-00. Standard test method for flexural properties of sandwich constructions ASTM International, West Conshohocken, PA, 2000.

[21] Guo, N., Leu, M. C. 2013. Additive manufacturing technology, applications and research needs Frontiers of Mechanical Engineering, 8(3), 215-243. 